\title{
Probiotic Potential of Lactobacillus Isolates
}

Ji Hun Bang', Hwa jin Shin', Hye Jung Choi², Dong Wan Kim ${ }^{3}$, Cheol Soo Ahn ${ }^{4}$, Young-Kee Jeong ${ }^{5}$ and Woo Hong Joo, ${ }^{1,2}$

${ }^{1}$ Department of Biology, Changwon National University, Changwon 641-773, Korea

${ }^{2}$ Department of Biology and Interdisciplinary Program in Biotechnology, Changwon National University, Changwon 641-773, Korea

${ }^{3}$ Department of Microbiology, Changwon National University, Changwon 641-773, Korea

${ }^{4}$ Cho-A Pharm Co, LTD., Haman-kun 637-810, Korea

${ }^{5}$ Department of Biotechnology, Dong-A University, Busan 604-174, Korea

Received February 19, 2012 /Revised February 15, 2012 /Accepted February 18, 2012

The purpose of this study was to investigate the probiotic properties of lactic acid bacterial strains isolated from animal feces. BCNU 9041 and BCNU 9042 isolates were assigned to Lactobacillus brevis on the basis of their physiological properties and $16 \mathrm{~S}$ ribosomal DNA sequences analysis. They were confirmed as safe bioresources because of their non-hemolytic activities and non-production of harmful $\beta$-glucosidase, $\beta$-glucuronidase, tryptophanase, or urease. These isolates were also highly resistant to acid (at $\mathrm{pH} 2.5$ ) and bile acids (at concentration of $0.3 \%, 0.6 \%$, and $1 \%$ oxgall). In addition, they exhibited good antibacterial activity against food-borne bacteria, especially Bacillus cereus, Listeria monocytogenes, and Shigella sonnei. Furthermore, it was demonstrated that they have the highest levels of hydrophobicity and that they showed bile salt hydrolytic and cholesterol assimilation activity. These results suggest that BCNU 9041 and 9042 have good potential for application in functional foods and health-related products.

Key words : Lactobacillus isolates probiotics, safe bioresources, hydrophobicity, cholesterol assimilation

\section{서 론}

사람과 동물의 위장관(gastrointestinal tract, $\mathrm{GIT}$ )에는 다양 한 미생물이 복합적으로 균총(microflora)을 이루고 있는데, 이들 균총은 동물의 종이나, 서식하고 있는 위장관의 위치에 따라 우점종(dominant species)의 차이를 나타내는 것으로 알 려져 있다[36]. 특히 돼지, 닭 및 설치류의 상부 위장관에는 비교적 많은 수의 미생물이 서식하고 있으며, 이들의 상부 위 장관의 비분비형 상피내벽 표면에는 Lactobacilli group이 주 로 부착되어 있는 것으로 알려져 있다[32]. Lactobacilli group 은 유산, 초산 등의 유기산과 nisin과 같은 단백질성 항균물질 인 bacteriocin을 생성함으로써 유해세균의 증식을 억제할 뿐 만 아니라 세균총의 안정화, 과민성대장증후군(irritable bowel syndrome, IBS), 유당 불내증(lactose intolerance) 및 비특이 적 면역증강의 완화, 나아가 항암 및 항종양 등의 유익한 기능 을 숙주에 대해 나타내는 것으로 알려져 있다 $[1,3,30,35]$. 이러 한 이유로 Lactobacillus 속 균주를 이용한 프로바이오틱스 (probiotics)에 대한 연구가 활발하게 진행되고 있으며, 프로바 이오틱스는 적정량을 섭취하였을 때 숙주의 건강에 유익한 영향을 미치는 살아있는 미생물로 정의되고 있다.

\section{*Corresponding author}

Tel : +82-55-213-3453, Fax : +82-55-213-3459

E-mail : whjoo@changwon.ac.kr
미생물이 프로바이오틱로서 이용되기 위해서는 안전성, 기 능성 및 기술적인 요소에서 검증을 거쳐야 하는데 최근에는 프로바이오틱스에 대한 규제 및 검증이 강화되고 있는 실정이 다[9,10,18]. 프로바이오틱스는 인돌(indole), 암모니아, 아민, 페놀과 같은 유해대사산물이나 대장암 원인효소인 $\beta$ -glucoronidase, tryptophanase 등의 유해효소를 생성하지 않 아야 하며, 장내 점질성 glycoprotein 분해능 및 급성 독성 (acute toxicity)이 없는 안전한 균이어야 한다[4,19,20,31]. 또한 인간과 동물의 장내 극한환경에서 생존하기 위해서는 위산에 대한 내성과 췌장효소 및 쓸개에서 분비되는 담즙에 대한 내 성을 지녀야 한다[7,14]. 숙주에 대하여 유익한 역할을 수행하 기 위해서는 장내 세포 표면의 부착능이 중요한 요소이며, 이 는 점막세포와 강한 비특이적 상호작용을 하는 세포 표면의 높은 소수성과 연관성이 높다는 연구 보고가 있다[11,27,29]. 최종적으로 프로바이오틱스의 제제화를 위한 공정과정에서 안정성 및 강한 생존력을 가지고 있어야 한다. 이러한 요건들 을 살펴보았을 때, 유산균은 장내의 낮은 $\mathrm{pH}$ 및 담즙산에 대한 내성을 지니며 안전성이 확보된 GRAS (generally regarded as safe) 미생물로 분류되고 있는 바 프로바이오틱스로서의 이용가치가 매우 높다고 판단된다[15,17]. 일찍이 유럽과 일본 에서는 L. rhumnosus GG (Valio, Finland), L. casei Shirota (Yakult, Japan) 등의 유산균을 분리하여 우수한 기능을 가진 프로바이오틱스로 개발하였으며, L. brevis, L. reuteri, L. sali- 
varius, L. gallinarum 등의 균주를 대상으로 다양한 기능에 대 한 연구가 활발히 진행되고 있다[2,5,26]. 국내에서도 마찬가지 로 김치 등의 발효식품, 동물, 인체 유래 균주를 분리하여 프로 바이오틱스로 사용하기 위한 연구가 활발히 진행 중이나 균주 의 확보가 가장 중요한 관건이다.

이에 본 연구에서는 다양한 유산균을 분리할 목적으로 건강 한 동물의 분변으로부터 유산균을 순수분리하여 선별하였으 며, 분자생물학적 동정을 시행하였다. 그리고 유해대사산물, 유해효소 생성 확인 등 기초적인 안전성을 검토한 토대위에 기능적 측면인 내산성, 내담즙성, 유해세균에 대한 항균활성, 세포표면 소수성 및 콜레스테롤 흡수 활성 등의 기능성을 조 사하여 그 결과를 보고한다.

\section{재료 및 방법}

\section{유산균의 분리 및 동정}

유산균의 분리를 위해 닭, 염소 및 돼지 등의 분변을 수집하 여 분리원으로 사용하였다. 각각의 시료를 멸균수에 희석하여 $0.5 \% \mathrm{CaCO}_{3}$ 를 함유한 MRS 평판배지에 $100 \mu 1$ 씩 도말하였으 며, $37^{\circ} \mathrm{C}$ 에서 24-48 시간 배양한 뒤 투명환을 생성하는 콜로니 를 선택하여 순수분리하였다. 분리된 균주의 $16 \mathrm{~S}$ ribosomal DNA 염기서열분석을 하였고, Genbank의 database에 등록된 다른 균들과 상동성을 비교, 분석하였다. 이들 결과에 기초하 여 clustal X2.0 (CLC bio, Denmark)을 사용하여 neighbor joining method를 기반으로 계통수를 작성하였고, 분리된 균 주의 생리, 생화학적 특징은 Bergey's manual of determinative bacteriology의 방법에 준하여 조사하였다[21,28].

\section{용혈성 등 안전성 조사}

용혈성 여부를 조사하기 위하여 선별된 유산균을 sheep blood agar plates(아산제약)에 접종하여 $37^{\circ} \mathrm{C}$ 에서 48 시간 배 양한 뒤 $a, \beta$, 및 $\lambda$ 용혈성을 확인하였다. 유해효소 생성능 조사는 선별균주의 배양액을 30 분간 원심분리 $\left(3000 \mathrm{rpm}, 4^{\circ} \mathrm{C}\right)$ 하여 침전물을 $20 \mathrm{mM}$ phosphate buffer (PBS, pH 7.0)로 현탁 시킨 후 $4^{\circ} \mathrm{C}$ 에서 2 분간 sonication하였다. 현탁액을 원심분리 한 다음 상등액을 조효소액으로 사용하여 대장암을 유발하는 효소인 $\beta$-glucosidase, $\beta$-glucoronidase, tryptophanse 및 urease에 대한 효소 활성 유무를 조사하였다[8].

\section{내산성 및 담즙산에 대한 내성 조사}

산에 대한 저항성을 알아보기 위해, 분리균주를 MRS broth에서 18 시간 배양한 뒤, $1 \mathrm{ml}$ 의 배양액을 $9 \mathrm{ml}$ 의 PBS buffer (pH 2.5)에 현탁하여 $37^{\circ} \mathrm{C}$ 에서 배양하였으며, 0 시간 과 3 시간 후의 생균수를 측정하였다. 담즙산에 대한 저항성 은 MRS broth에서 18 시간 배양한 균주를 $0.3 \%, 0.6 \%, 1 \%$ (w/v)의 oxgall이 포함되어 있는 $9 \mathrm{ml}$ 의 MRS broth에 $1 \mathrm{ml}$
씩 접종하였으며, 0 과 24 시간 후의 생균수를 측정하였다. 생 균수는 $\mathrm{MRS}$ 평판배지에서 48 시간 동안 $37^{\circ} \mathrm{C}$ 에 배양하여 측정하였다[33].

\section{항균력 조사}

식중독 원인균인 Bacillus cereus ATCC 14579, Listeria monocytogenes ATCC 15313, Staphylococcus aureus ATCC 6538, Escherichia coli ATCC 10798, Salmonella typhimurium ATCC 14028, Shigella sonnei ATCC 25931에 대한 분리균주의 항균력 조사하였다[23]. 분리균주를 $37^{\circ} \mathrm{C}$ 에서 24 시간 배양한 후 균체 를 제거한 뒤 $\mathrm{pH}$ 를 중성화시킨 배양상등액과 $\mathrm{pH}$ 를 조정하지 않은 상등액 각각을 $0.22 \mu \mathrm{m}$ membrane 필터로 여과하여 항균 력 측정을 위한 시료로 사용하였다. 각각의 시료를 $8 \mathrm{~mm}$ 의 paper disk에 75 씨씩 흡수시켰으며, 식중독 원인균이 도말된 고체배지에 이들 paper disk를 올려놓고 $37^{\circ} \mathrm{C}$ 에서 8-12 시간 배양한 후 생육억제환을 측정하였다.

\section{항생제 감수성}

항생제 감수성은 disk diffusion method법으로 측정하였다 [24]. 분리된 유산균을 MacFarland scale 0.5 로 보정하였으며, MRS 평판배지에 $100 \mu \mathrm{l}$ 분주하여 도말하였다. 유산균이 도말 된 배지에 농도별로 접종된 항생제 paper disk를 올려 놓고 $37^{\circ} \mathrm{C}$ 에서 24 시간 배양하여 항생제의 최소억제범위를 조사하 였다.

\section{세포표면 소수성}

실험 균주의 세포표면 소수성 검사는 Doyle 등의 방법으로 실시하였다[6]. 실험 균주를 MRS broth에 접종한 뒤 $37^{\circ} \mathrm{C}$ 에 서 18 시간 배양하였다. 배양액을 원심분리하여 균체를 회수 하였으며 quarter-strength Ringer's 용액으로 두 번 washing 한 다음 같은 용액으로 현탁하였다. 현탁액과 $n$-hexadecane, chloroform를 각각 1:1의 비율로 첨가한 뒤 2 분 동안 vortex 후 30 분 동안 상온에 방치하여 층이 분리되도록 하였다. 시험 균주의 현탁액과(reading 1) 분리된 층의 수용성 층에 (reading 2) 대한 흡광도를 $580 \mathrm{~nm}$ 에서 측정하였으며 소수성 의 계산은 다음과 같이 측정하였다. 모든 실험은 3 회 반복하 여 수행하였다.

$\%$ hydrophobicity $=[(\mathrm{OD} 580 \mathrm{~nm}$ reading $1-\mathrm{OD} 580 \mathrm{~nm}$ reading 2)/ OD $580 \mathrm{~nm}$ reading 1] $\times 100$.

\section{Bile salt hydrolase (BSH) 활성과 cholesterol 흡수 활성 조사}

실험균주의 BSH 활성을 조사하기 위해 BSH medium (MRS agar, $0.5 \%$ sodium salt of taurodeoxycholic acid (TDCA), $0.37 \mathrm{~g} \mathrm{CaCl}_{2} / \mathrm{l}$ )에 실험균주의 배양액을 $10 \mu \mathrm{ll}$ 점적하 였으며, $37^{\circ} \mathrm{C}$ 에서 72 시간 배양한 뒤 흰색환의 생성여부로 판 
단하였다. 콜레스테롤 흡수(cholesterol assimilation) 활성 조 사는 실험균주를 $0.5 \%(\mathrm{w} / \mathrm{v})$ TDCA와 $0.1 \mathrm{~g} / 1$ 수용성 cholesterol을 첨가한 MRS broth에 접종하여 $37^{\circ} \mathrm{C}$ 에서 24 시간 배양 하였다. 배양액을 $10,000 \mathrm{rpm}$ 으로 5 분간 원심분리하여 균체 를 제거한 뒤 배양 상등액을 획득하였으며, 콜레스테롤은 Rudel과 Morris 법에 준하여 정량적으로 측정하였다[22]. 균 주를 접종하지 않은 MRS broth를 대조구로 사용하였다.

\section{결 과}

\section{유산균의 분리 및 동정}

건강한 가축의 분변으로부터 100 여 균주를 분리하였으며, $\mathrm{CaCO}_{3}$ 를 함유한 MRS agar에서 넓은 투명환을 생성하는 4 균을 선발하여 BCNU 9036, BCNU 9041, BCNU 9042, BCNU 9043으로 명명하였다. 16S ribosomal DNA 염기서열을 바탕 으로 계통수를 확인한 결과 이들 모든 균주가 Lactobacillus group에 속함을 알 수 있었으며, $\mathrm{NCBI}$ 의 blast program을 이 용하여 상동성을 비교하였을 때 BCNU 9036은 L arizonensis, $\mathrm{BCNU}$ 9041과 $\mathrm{BCNU}$ 9042은 L. brevis와 BCNU 9043은 L salivarius와 $99 \%$ 의 가장 높은 상동성을 보였다(Fig. 1). 분리균주 의 생리, 생화학적 특징을 조사한 결과 그람양성 세균임을 확 인하였으며, $37^{\circ} \mathrm{C}$ 의 온도에서 가장 잘 생육하는 것으로 조사 되었다. $\mathrm{NaCl} 3-7 \%$ 에서 생육하며, 균에 따른 차이는 나타나지 만 산성과 알칼리성의 폭넓은 $\mathrm{pH}$ 에서 생육하는 것을 확인할
수 있었다. 그리고 이들 균주들은 glucose, lactose 및 sucrose 등 탄소원을 발효함이 확인되었다(Table 1).

\section{용혈성 등 안전성 조사}

분리균주 Lactobacillus BCNU 9036, BCNU 9041, BCNU 9042 및 BCNU 9043은 적혈구의 파괴 또는 분해현상인 용혈현 상을 나타내지 않았으며, 유해대사산물로 알려진 indole, phenylpyruvic acid를 생성하지 않았다. 또한 암형성에 유의한 $\beta$ glucosidase, $\beta$ - glucoronidase, tryptophanase, 그리고 urease 를 생성하지 않아 전체적으로 프로바이오틱 균주로서 사용상 안전성이 있는 것으로 확인되었다(Table 2).

\section{내산성 및 담즙산에 대한 내성 조사}

동정된 4균주를 대상으로 $\mathrm{pH}$ 대한 내성을 조사한 결과 $\mathrm{pH}$ 2.5 의 PBS buffer에서 BCNU 9041, BCNU 9042는 각각 96.3\%, $91.6 \%$ 의 높은 생존률을 나타내었고, BCNU 9036, 9043은 50\%, $31 \%$ 의 다소 낮은 생존률을 보였다(Fig. 2). $0.3 \%, 0.6 \%, 1 \%$ 의 oxgall을 첨가한 배지에서 내 담즙산을 측정한 결과 내산성에 서 높은 생존률을 나타내었던 BCNU 9041, BCNU 9042는 $0.3 \%, 0.6 \%, 1 \%$ 의 oxgall에서도 오히려 균이 증식하거나 전혀 저해를 받지 않은 것으로 조사되었다(Fig. 3). 반면, $\mathrm{BCNU}$ 9043은 $0.3 \%$ 의 oxgall에서 $28 \%$ 의 낮은 생존률을 나타내었고 $\mathrm{BCNU}$ 9036의 경우 $0.3 \%$ 의 oxgall에서만 $2.2 \%$ 의 생존률을 나 타내었다. 균주의 내산성 및 내답즙산의 능력에서 볼 때 분리

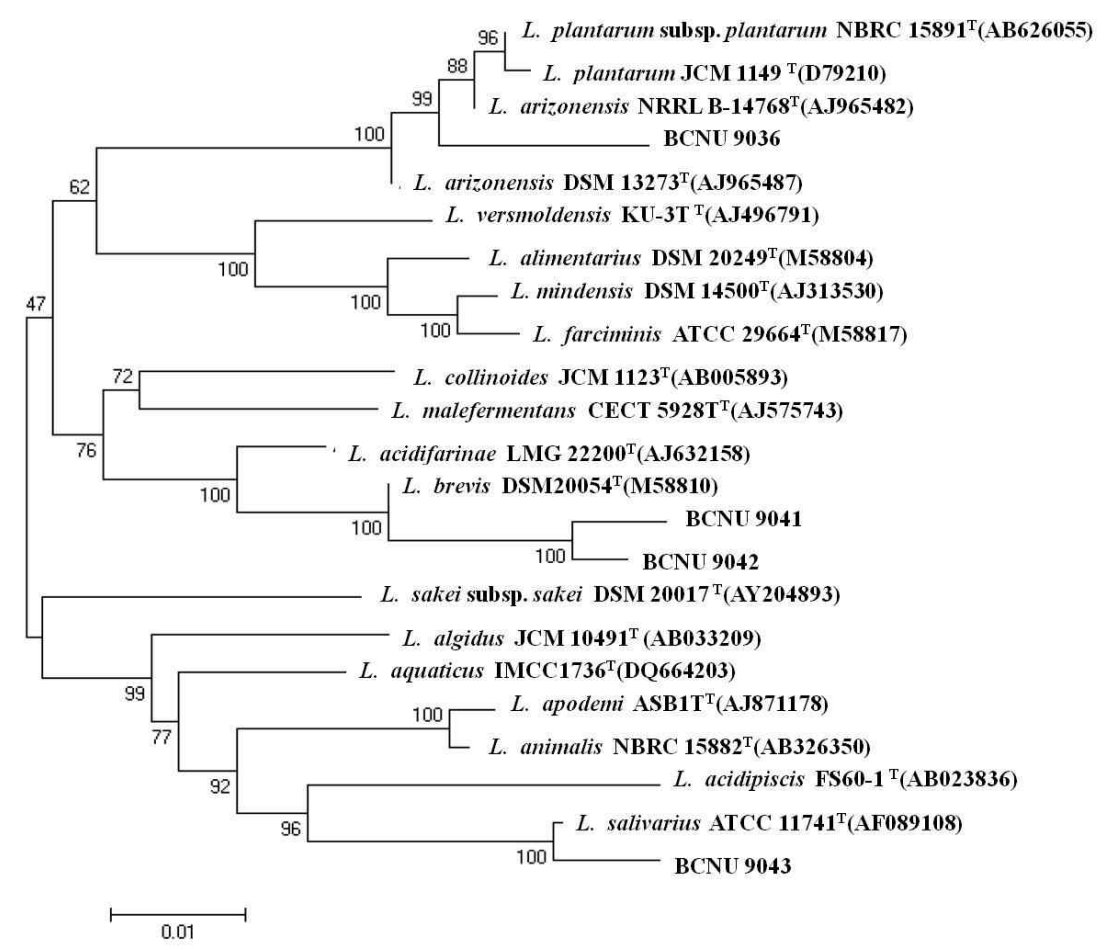

Fig. 1. A phylogenetic tree, showing the position of Lactobacillus strains among the Lactobacillus species. 
Table 1. Physiological properties of selected Lactobacillus strains

\begin{tabular}{|c|c|c|c|c|}
\hline Characteristic $^{1)}$ & BCNU 9036 & BCNU 9041 & BCNU 9042 & BCNU 9043 \\
\hline Gram's reaction $^{1)}$ & + & + & + & + \\
\hline Optinum growth temperature $\left({ }^{\circ} \mathrm{C}\right)$ & $37^{\circ} \mathrm{C}$ & $37^{\circ} \mathrm{C}$ & $37^{\circ} \mathrm{C}$ & $37^{\circ} \mathrm{C}$ \\
\hline Growth $\mathrm{pH}$ & $2.5-9$ & $2-9$ & $2-9$ & $2.5-9$ \\
\hline Growth $\mathrm{NaCl}(\%)$ & $3-5 \%$ & $3-5 \%$ & $3-5 \%$ & $3-5 \%$ \\
\hline \multicolumn{5}{|l|}{ Utilization of carbohydrates ${ }^{2)}$} \\
\hline Arabinose & - & - & - & - \\
\hline Cellobiose & - & - & - & - \\
\hline Fructose & + & \pm & + & + \\
\hline Galactose & + & \pm & \pm & + \\
\hline Glucose & + & + & + & + \\
\hline Lactose & + & + & + & + \\
\hline Mannose & + & + & + & + \\
\hline Monnitol & + & + & + & + \\
\hline Raffinose & + & + & + & + \\
\hline Rhamnose & - & - & - & - \\
\hline Sucrose & + & + & + & + \\
\hline Xylose & - & + & + & + \\
\hline
\end{tabular}

${ }^{1)}+$ : Gram positive, - : Gram negative

${ }^{2)}+$ : positive utilization, \pm : utilization doubtful, -: negative utilization.

Table 2. Haemolytic activity, production of harmful metabolites and enzyme of Lactobacillus strains

\begin{tabular}{lccccc}
\hline & E. coli ${ }^{1)}$ & BCNU 9036 & BCNU 9041 & BCNU 9042 & BCNU 9043 \\
\hline Haemolysis & $-{ }^{2)}$ & - & - & - & - \\
B-glucosidase & + & - & - & - & - \\
B-glucuronidase & + & - & - & - & - \\
Tryptophanase & + & - & - & - & - \\
Urease & - & - & - & - & - \\
Gelatinase & - & - & - & - & - \\
Indole & + & - & - & - & - \\
Phenylpyruvic acid & - & & & - \\
\hline
\end{tabular}

${ }^{1)}$ Positive control: E. coli ATCC 10798

${ }^{2)}+$ : positive, -: negative

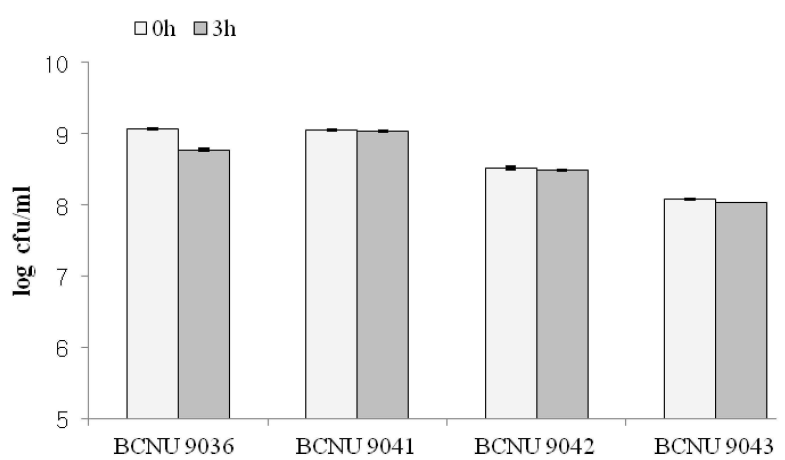

Fig. 2. Acid tolerance of Lactobacillus strains.

균주 $\mathrm{BCNU} 9041$ 및 9042 는 장내의 극한 환경에서 생존가능성 이 높을 것으로 확인되어 프로바이오틱스 균주로 안정성이 높다고 판단된다.

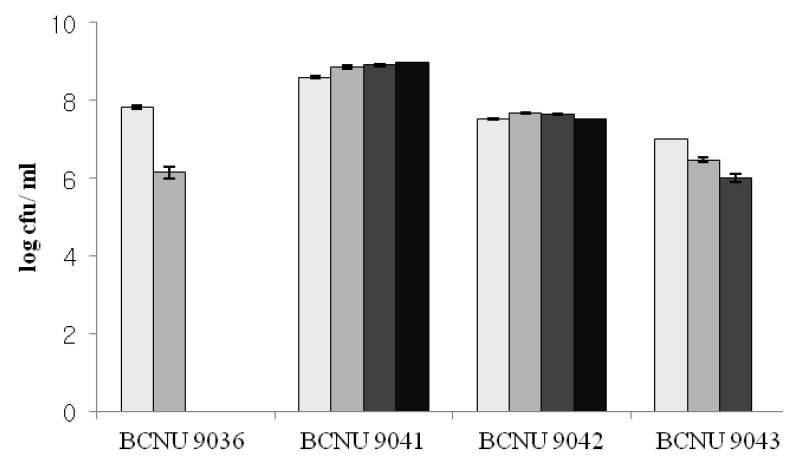

Fig. 3. Bile salt tolerance of Lactobacillus strains.

\section{항균력 조사}

분리균주의 식중독 원인균에 대한 항균활성을 조사한 결과, $\mathrm{pH}$ 를 중성화 시킨 시료에서는 항균활성이 나타나지 않았으나, 

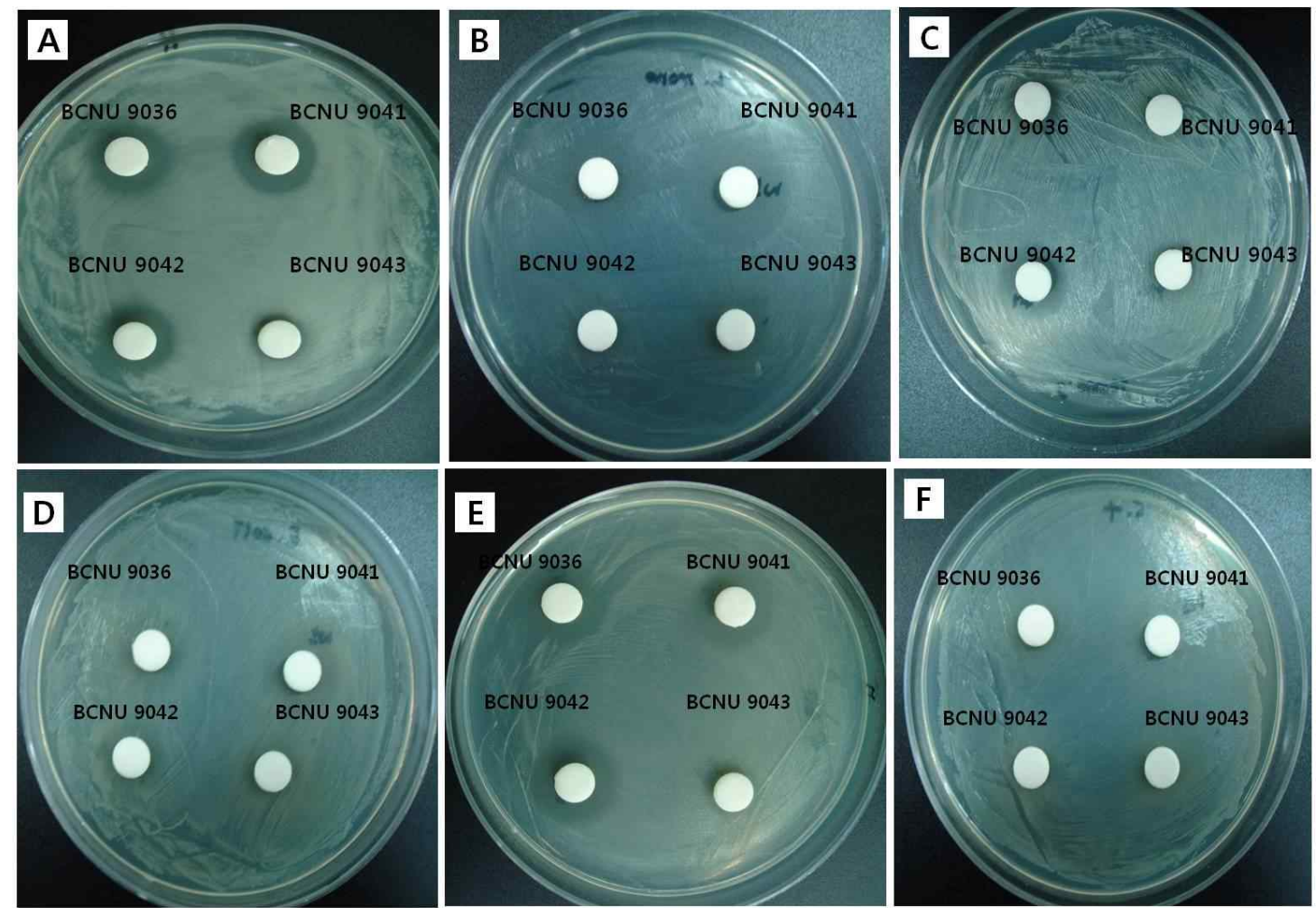

Fig. 4. Antimicrobial activities of Lactobacillus strains against food pathogens. (A) B. cereus, (B) L. monocytogenes, (C) S. aureus, (D) E. coli, (E) S. sonnei, (F) S. typhymurium

Table 3. Antimicrobial activities of Lactobacillus strains against food pathogens

\begin{tabular}{lcccccc}
\hline & B. cereus $^{1)}$ & L. monocytogenes & S. aureus & E. coli & S. sonnei & S. typhimurium \\
\hline BCNU 9036 & $14.5 \pm 0.7^{2)}$ & $10 \pm 0.7$ & $10 \pm 0.7$ & - & $11.5 \pm 0.7$ & - \\
BCNU 9041 & $16 \pm 0.0$ & $18 \pm 0.5$ & $9 \pm 0.0$ & - & $16 \pm 1.4$ & - \\
BCNU 9042 & $16 \pm 0.0$ & $10 \pm 0.0$ & $12 \pm 0.5$ & - & $16 \pm 0.0$ & - \\
BCNU 9043 & $10 \pm 0.3$ & $12 \pm 0.0$ & $10 \pm 1.4$ & - & $9 \pm 0.5$ & - \\
\hline
\end{tabular}

${ }^{1)}$ paper disk $8 \mathrm{~mm}$

${ }^{2)}$ Each value in the table represents the mean value \pm standard deviation (SD) from three trials.

$\mathrm{pH}$ 를 조정하지 않은 시료에서는 균에 따라 차이를 보이지만 항 균활성을 나타낸 것을 확인하였다. 특히 그람양성 세균인 B. cereus, L monocytogenes, S. aureus에 대한 항균활성이 우수하였고 그람음성 세균인 S. sonnei에 대해서도 항균활성이 관찰되었지 만 E. coli와 S. typhimuriump에 대해서는 항균활성이 관찰되지 않 음을 확인하였다. 균주를 배양한 MRS broth의 $\mathrm{pH}$ 는 6.4 였으 며, 배양여액의 $\mathrm{pH}$ 는 균에 따른 차이는 있었지만 $\mathrm{pH}$ 3.8-4.5 사 이로 측정되었으며, 이러한 결과는 분리균주가 생산하는 유기 산, 초산 등의 생성물에 의해 항균활성을 나타내는 것으로 판단 된다(Fig. 4, Table 3).

\section{항생제 감수성}

분리균주 BCNU 9041및 BCNU 9042는 penicillin계 ampi- cillin, aminoglycoside계 gentamicin, tetracycline계 tetracycline 및 기타 chloramphenicol 항생제에 대해 감수성을 나타 내었고, aminoglycoside계 항생제 streptomycin에 대해서는 내성을 나타내었다. BCNU 9036은 gentamicin, tetracycline에 대하여 $30 \mu \mathrm{g} / \mathrm{ml}$ 의 농도에서 내성을 나타내었으며 $\mathrm{BCNU}$ 9043은 gentamicin에 대해서는 내성을 나타내었지만 streptomycin에 대해서는 내성이 없는 것으로 조사되었다(Table 4).

\section{세포 표면 소수성}

가축의 분변으로부터 분리한 균주의 소수성 실험결과 n-hexadecane에 대해서 $\mathrm{BCNU} 9041$ 및 9042 균주는 각각 $95 \%, 92 \%$ 로 높은 소수성을 나타내었고, BCNU 9043 은 $80 \%$ 이상의 소수성을 나타내었다. 반면 BCNU 9036 는 $20 \%$ 의 낮은 
Table 4. Antibiotics susceptibility of Lactobacillus strains

\begin{tabular}{lccccc}
\hline & Disc conc. & BCNU $9036^{2)}$ & BCNU 9041 & BCNU 9042 & BCNU 9043 \\
\hline Ampicillin & 10 & $\mathrm{~S}$ & $\mathrm{~S}$ & $\mathrm{~S}$ & $\mathrm{~S}$ \\
Chloramphenicol & 10 & $\mathrm{~S}$ & $\mathrm{~S}$ & $\mathrm{~S}$ & $\mathrm{~S}$ \\
Gentamicin & 30 & $\mathrm{R}$ & $\mathrm{S}$ & $\mathrm{S}$ & $\mathrm{R}$ \\
Streptomycin & 7.5 & $\mathrm{~S}$ & $\mathrm{R}$ & $\mathrm{S}$ \\
Tetracycline & 7.5 & $\mathrm{R}$ & $\mathrm{S}$ & $\mathrm{S}$ & $\mathrm{R}$ \\
\hline
\end{tabular}

${ }^{1)}$ disk concentration : $\mu \mathrm{g} / \mathrm{ml}$,

${ }^{2)} \mathrm{R}$; resistant, $\mathrm{S}$; sensitive.

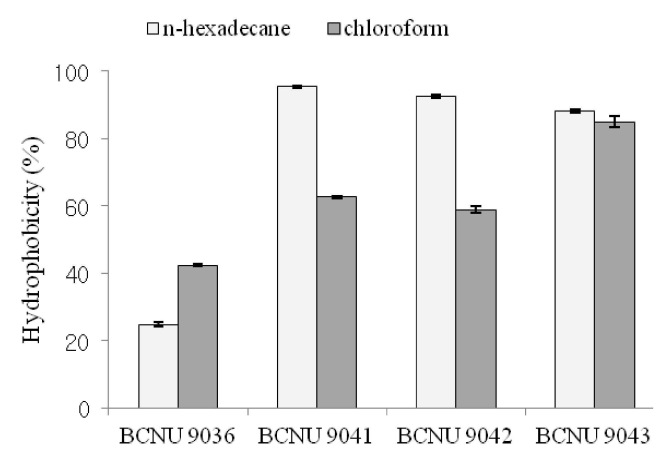

Fig. 5. Hydrophobicity of Lactobacillus strains.

Table 5. Bile salt hydrolase activity and cholesterol assimilation of selected potential Lactobacillus

\begin{tabular}{ccc}
\hline \multirow{2}{*}{ Strains } & BSH & \multicolumn{2}{c}{$\begin{array}{c}\text { Cholesterol assimilation in the } \\
\text { presence of taurodeoxycholic acid }\end{array}$} \\
\cline { 3 - 3 } & activity & $\%$ assimilation \\
\hline BCNU 9041 & $+{ }^{1)}$ & $66.24 \pm 2.05^{2)}$ \\
BCNU 9042 & + & $69.85 \pm 2.84$ \\
\hline
\end{tabular}

${ }^{1)}+$ : Positive BSH activity, -: negative BSH activity

${ }^{2)}$ Each value in the table represents the mean value \pm standard deviation (SD) from three trials.

소수성 값이 측정 되었다. Chloroform에 대해서 BCNU 9043, 9041 및 9042는 85\%-58\% 사이로 높은 소수성을 나타내었다 (Fig. 5).

\section{Bile salt hydrolase (BSH) 활성과 콜레스테롤 흡수활성} 조사

$\mathrm{BCNU} 9041$ 및 9042의 $\mathrm{BSH}$ 활성을 조사한 결과 흰색환을 생성하여 효소활성이 있음이 확인되었다. 또한 BCNU 9041 및 9042 는 각각 $66 \%, 69 \%$ 로 우수한 콜레스테롤 흡수현상을 나타내었다(Table 5).

\section{고 찰}

현재 사회적으로 건강에 대한 관심이 매우 높으며 이에 따 라 기능성 식품 또는 의약품으로 개발되어 판매되고 있는 프
로바이오틱 제제에 대한 관심도 커지고 있다. 국내에서도 이 러한 흐름에 따라 프로바이오틱스에 대한 연구가 활발히 진행 되고 있지만 다양한 균주의 확보는 미흡한 수준이므로 프로바 이오틱스 균주의 확보가 절실히 요구된다. 특히 제제로 이용 되는 기존의 균주보다 더욱 향상된 기능을 가지며 동시에 안 전성과 안정성을 갖추고 있는 균주에 대한 탐색과 선별이 필 요한 실정이다[16]. BCNU 9041 및 BCNU 9042 균주는 건강한 가축의 분변으로부터 분리되었으며, 분자생물학적 동정에 따 라 두 균주 모두 Lactobacillus brevis와 99\% 상동성을 가진 것으 로 확인되었다. Lactbacillus brevis BCNU 9041 및 BCNU 9042 는 산성 및 담즙산에 대한 내성이 우수한 것으로 조사되어 위장관내에서의 생존가능성을 기대할 수 있었다. 콜레스테롤 을 분해하는 균주는 담즙산에 대한 저항성 및 담즙산의 탈포 합(deconjugation) 능력이 강한 특징이 있다고 보고되고 있다 [12,13]. 두 균주 모두 1\% oxgall이 포함된 배지에서도 전혀 저해를 받지 않는 것으로 나타나, 콜레스테롤 분해기능에 대 한 잠재적인 가능성을 가지고 있다고 판단된다.

$\mathrm{BCNU}$ 9041과 $\mathrm{BCNU}$ 9042의 세포 표면 소수성을 검토한 결과 $90 \%$ 이상의 높은 소수성을 나타내었는데, 세포 표면 소 수성이 $85 \%$ 이상이 되어야 장 상피세포 부착성에 도움을 준다 는 Perez 등의 연구와 비교했을 때, BCNU 9041 과 BCNU 9042 는 장 상피세포의 부착성이 높을 것으로 사료된다[25]. 장 상피 세포에 대한 부착능은 Caco 2 cell 등을 대상으로 추후 검증을 하여야 되며 마우스 실험 등을 통하여 실증적 확인이 되어야 할 과제이다. 또한 식중독 세균에 대한 다소 넓은 항균 스펙트 럼을 확인할 수 있었다. 이들 결과에서 장내 유해세균이 증가 하였을 경우, 장내 세균총의 안정화 및 유해세균 억제효과를 기대할 수 있다. 그러나 항균력을 가진 물질의 생성여부와 생 성량 그리고 물질의 구조동정에 관한 구체적인 연구를 통하여 항균 기능은 자세히 검증되어야 할 것이다. $\mathrm{BSH}$ 활성은 혈중 의 cholesterol 조절에 관여하는 장관순환에 중요한 역할을 하 는 것으로 알려져 있으며 cholesterol assimilation은 세포벽의 peptidogycan의 구조적, 화학적 특성에 의한 것으로 콜레스테 롤 저하 기작 중의 하나로 밝혀져 있다[34]. BCNU 9041 및 9042는 BSH 활성을 가진 것으로 나타났으며 cholesterol assimilation이 66-69\%으로 조사된 바 두 균주 모두 우수한 콜레 
스테롤 조절 및 억제능을 가진 것으로 판단된다. 이러한 결과 들을 바탕으로 동물의 분변으로 분리된 Lactobacillus sp. $\mathrm{BCNU} 9041$ 및 BCNU 9042 균주는 우수한 probiotic 자원으로 사료되며, 콜레스테롤 감소 등 다양한 기능을 가진 신규바이 오 소재로 판단된다.

\section{감사의 글}

본 연구는 교육과학기술부와 한국연구재단의 지역혁신 인 력양성사업으로 수행된 연구결과이므로 이에 감사드립니다.

\section{References}

1. Alander, M., Satokari, R., Korpela, R., Saxelin, M., Vilpponen-Salmela, T. and von Wright. A. 1999. Persistence of colonization of human colonic mucosa by a probiotic strain, Lactobacillus rhamnosus GG, after oral consumption. Appl. Environ. Microbiol. 65, 351-354.

2. Anderson, J. W. and Gilliland, S. E. 1999. Effect of fermented milk (yogurt) containing Lactobacillus acidophilus L1 on serum cholesterol in hypercholesterolemic humans. J. Am Coll. Nutr. 18, 43-50.

3. Axelsson, L. T., Chung, T. C., Dobrogosz, W. G. and Lindgren, S. E. 1989. Production of a broad spectrum antimicrobial substance by Lactobacillus reuteri. Microb. Ecol. Health Dis. 2, 131-136.

4. Lee, D. Y., Seo, Y. S., Rayamajhi, N., Kang, M. L., Lee, S. I. and Yoo, H. S. 2009. Isolation, characterization, and evaluation of wild isolates of Lactobacillus reuteri from pig feces. J. Microbiol. 47, 663-672.

5. Coconnier, M. H., Levien, V., Hemery, E. and Servin, A. L. 1998. Antagonistic activity against Helicobacter infection in vitro and in vivo by the human Lactobacillus acidophilus strain LB. Appl. Environ. Microbiol. 64, 4573-4580.

6. Doyle, R. J. and Rosenberg, M. 1995. Measurement of microbial adhesion to hydrophobic substrates. Methods Enzymol. 253, 542-550.

7. Dunne, C., Murphy, L., Morrissey, D., Thornton, G., O'Halloran, S., Feeney, M., Flynn, S., Fitzgerald, G., Daly, C., Kiely, B., O'Sullivan, G. C., Shanahan, F. and Collins, J. K. 2001. In vitro selection criteria for probiotic bacteria of human origin: correlation with in vivo findings. $A m ~ J$. Clin. Nutr. 73, 386S-392S.

8. Donohue, D. C. and Salminen, S. 1996. Safety of probiotic bacteria. Asia Pac. J. Clin. Nutr. 5, 25-28.

9. Fukushima, Y., Kawata, Y., Hara, H., Terada, A. and Mitsuoka. T. 1998. Effect of a probiotic formula on intestinal immunoglobulin a production in healthy children. Int. J. Food Microbiol. 30, 39-44.

10. Fuller, R. and Gibson, G. R. 1997. Modification of the intestinal microflora using probiotics and prebiotics. Scand J. Gastroenterol. Suppl. 32, 28-31.

11. Granato, D., Perotti, F., Masserey, I., Rouvet, M., Golliard,
M., Servin, A. and Brassart, D. 1999. Cell surface-associated lipoteichoic acid acts as an adhesion factor for attachment of Lactobacillus johnsonii La1 to human enterocyte-like Caco-2 cells. Appl. Environ. Microbiol. 65, 1071-1077.

12. Gilliland, S. E., Nelson, C. R. and Maxwell, C. 1985. Assimilation of cholesterol by Lactobacillus acidophilus. Appl. Environ. Microbiol. 49, 377-381.

13. Gilliland, S. E. and Walker, D. K. 1990. Factors to consider when selecting a culture to produce of Lactobacillus acidophilus as a dierary adjunct to produce a hypocholesterolemic effect in humans. J. Dairy Sci. 73, 905-911.

14. Henriksson, A., Khaled, A. K. D. and Conway, P. L. 1999. Lactobacillus colonization of the gastrointestinal tract of mice after removal of the non-secreting stomach region. Microb. Ecol. Health Dis. 11, 96-99.

15. Holzapfel, W. H., Geisen, R. and Schillinger, U. 1993. Biological preservation of foods with reference to protective cultures, bacteriocins and food-grade enzymes. Int. J. Food Microbiol. 24, 343-362.

16. Ishibashi, N. and Yamazaki, S. 2001. Probiotics and safety. Am J. Clin. Nutr. 73, 465S-470S.

17. Isolauri, E., Salminen, S. and Ouwehand, A. C. 2004. Microbial-gut interactions in health and disease. Probiotics. Best Prac. Res. C. Em 18, 299-313.

18. Isolauri, E., Sütas, Y., Kankaanpää, P., Arvilommi, H. and Salminen, S. 2001. Probiotics: effects on immunity. Am J. Cin. Nutr. 73, 444S-450S.

19. Maragkoudakisa, P. A., Zoumpopouloua, G., Miarisa, C., Kalantzopoulosa, G., Potb, B. and Tsakalidou, E. 2006. Probiotic potential of Lactobacillus strains isolated from dairy products. Int. Dairy J. 16, 189-199.

20. Cole, C. B., Fuller, R. and Carter, S. M. 1989. Effect of probiotic supplements of Lactobacillus acidophilus and Bifidobacteriurn adolescentis 2204 on $\beta$-glucosidase and $\beta$ -glucuronidase activity in the lower gut of rats associated with a human faecal flora. Microb. Ecol. Health D. 2, 223-225.

21. Knadler, O. and Weiss, N. 1986. Regular, nonsporing gram-positive rods. pp. 1208-1234. In Sneath, P. H. A., Mair, N. S., Sharpe, M. E. and Holt, J. G. (eds.), Bergey's Manual of Systematic Bacteriology, Vol. 2, Williams \& Wilkins, Baltimore.

22. Mathara, J. M., Schillinger, U., Guigas, C., Franz, C. M. A. P., Kutima, P. M., Mbugua, S., Shin, H. K. and Holzapfel, W. H. 2008. Functional characteristics of Lactobacillus spp. Form traditional Maaasai fermented milk products in Kenya, Int. J. Food Microbiol. 126, 57-64.

23. Mishra, V. and Prasad, D. N. 2005. Application of in vitro methods for selection of Lactobacillus casei strains as potential probiotics. Int. J. Food Microbiol. 103, 109-115.

24. Perez, C., Pauli, M. and Bazerque, P. 1990. An antibiotics assay by agar well diffusion method. ActaBiol. Med Exp. 15, 113-115.

25. Perez, P. F., Minnard, Y., Disalvo, E. A. and Antoni, G. L. 1998. Surface properties of bifidobacteria strains of human origin. Appl. Environ. Microbiol. 64, 21-26.

26. Ramasamy, K., Abdullah, N., Wong M. C., Karuthan, C. and 
Ho, Y. W. 2010. Bile salt deconjugation and cholesterol removal from media by Lactobacillus strains used as probiotics in chickens. J. Sci. Food Agric. 15, 65-69.

27. Ross, S. and Jonsson, H. 2002. A high-molecular mass cell surface protein from Lactobacillus reuteri 1063 adheres to mucus components. Microbiology 148, 433-442.

28. Saitou, N. and Nei, M. 1987. The neighbor-joining method: a new method for reconstructing phylogenetic trees. Mol. Biol. Evol. 4, 406-425.

29. Schar-Zammaretti, P. and Ubbink, J. 2003. The cell wall of lactic acid bacteria: surface constituents and macromolecular conformations. Biophys. J. 85, 4076-4092.

30. Seo J. G., Lee, G. S., Kim, J. E. and Chung, M. J. 2010. Development of probiotic products and challengers. $K S B B$ J. 25, 303-310.

31. Sorokulova, I. B., Pinchuk, I. V., Denayrolles, M., Osipova, I. G., Huang, J. M., Cutting, S. M. and Urdaci, M. C. 2008. The safety of two Bacillus probiotic strains for Human Use. Digest. Dis. Sci. 53, 954-963.
32. Tannock, G. W. 1995. Normal microflora: an introduction to microbes inhabiting the human body. Chapman and Hall London, United Kingdom.

33. Thirabunyanon, M., Boonprasom, P. and Niamsup, P. 2009. Probiotic potential of lactic acid bacteria isolated from fermented dairy milks on antiproliferation of colon cancer cells. Biotechnol. Lett. 31, 571-576.

34. Toit, M., Franz, C. M., Dicks, L. M., Schillinger, U., Haberer, P., Warlies, B., Ahrens, F. and Holzapfel, W. H. 1998. Characterisation and selection of probiotic lactobacilli for a preliminary minipig feeding trial and their effect on serum cholesterol levels, faeces $\mathrm{pH}$ and faeces moisture content. Int. J. Food Microbiol. 40, 93-104.

35. Vrese, M., Stegelmann, A., Ritcher, B., Fenselau, S., Laue, C. and Schrezenmeir, J. 2001. Probiotics: compensation for lactase insufficiency. Am J. Clin. Nutr. 73, S421-S429.

36. Walter, J. 2008. Ecological role of lactobacilli in the gastrointestinal tract: implications for fundamental and biomedical research. Appl. Environ. Microbiol. 74, 4985-4996.

\section{초록 : Lactobacillus 분리균주의 프로바이오틱스로서의 가능성 검토}

방지훈 ${ }^{1} \cdot$ 신화진 $^{1} \cdot$ 최혜정 $^{2} \cdot$ 김동완 $^{3} \cdot$ 안철수 $^{4} \cdot$ 정영기 $^{5} \cdot$ 주우홍 ${ }^{1,{ }_{\star}}$

('창원대학교 생물학과, ${ }^{2}$ 창원 대학교생명공학협동과정, ${ }^{3}$ 창원대학교 미생물학과, ${ }^{4}$ 조아제약(주, ${ }^{5}$ 동아대학교 생명공학과)

본 연구는 동물의 분변으로부터 분리한 유산균의 프로바이오틱 특성을 조사할 목적으로 시행되었다. 생리생화 학적 특성과 $16 \mathrm{~S}$ 리보솜 DNA 분석 결과 BCNU 9041, 9042는 Lactobacillus brevis와 $99 \%$ 의 상동성을 나타내었다. 이들 균주를 대상으로 기초적인 안전성 실험을 시행한 결과, 이들 균주는 용혈현상이 나타나지 않으며 $\beta$ -glucosidase, $\beta$ - glucuronidase, tryptophanase 및 urease와 같은 유해한 생성물을 생성하지 않는 안전한 생물자 원임이 확인되었다. BCNU 9041 및 9042 은 $\mathrm{pH} 2.5$ 의 산성 조건 및 담즙에서 $(0.3,0.6,1 \%$ 의 oxgall이 포함된 MRS broth) 높은 생존률을 나타내었다. 뿐만 아니라 식중독 원인 세균에 대하여 항균활성을 가지고 있으며, 특히 Bacillus cereus, Listeria monocytogenes 및 Shigella sonnei 에 대한 항균활성이 뛰어났다. 또한 BCNU 9041, BCNU 9042은 92-95\%의 높은 소수성과 BSH (bile salt hydrolytic) 활성 및 cholesterol 흡수력이 우수함이 확인되었다. 이들 결과를 바탕으로 프로바이오틱로서의 우수한 기능성을 가진 BCNU 9041와 BCNU 9042의 기능성 식품 및 건강관련 제품으로의 활용이 기대된다. 